\title{
PENGARUH LINGKUNGAN KERJA, KOMITMEN PROFESI, MOTIVASI DAN STRES KERJA TERHADAP KINERJA PEGAWAI PADA KANTOR PELAYANAN PAJAK PRATAMA PEKANBARU TAMPAN
}

\author{
Santi Liasari Harahap \\ Universitas Islam Sumatera Utara \\ Santi.liasari@gmail.com
}

\begin{abstract}
The problems in this research are: how the influence of the work environment, professional commitment, motivation and work stress partially and jointly on the performance of employees at the Pratama Pekanbaru Tax Service Office Handsome? Research objectives: To find out the effect of the work environment, professional commitment, work motivation and stress partially and jointly on employee performance at the Pratama Pekanbaru Tax Office Handsome. The hypothesis proposed is: Work environment, professional commitment, work motivation and stress partially and simultaneously have a significant effect on employee performance at the Pratama Pekanbaru Tampan Tax Office. The study was conducted at the Pratama Pekanbaru Tax Service Office Handsome Road Ring Road Arengka II / SM Amin Road Simpang Baru Pekanbaru, with a population of 98 people, and a study sample of 96 people. Based on the results of the analysis, there is a significant influence between the work environment on the performance of the Pratama Pekanbaru Tampan Tax Office employees, because according to the results of the analysis $t$ count $>$ t-table (2.932> 1.67) at $n=96$ with a 95\% significance level. There is a significant influence between the professional commitment to the performance of the Pratama Pekanbaru Tampan Tax Office employees, the result of the analysis is $t$ count $>t$-table (1.975> 1.67) at $n=96$ with a significance level of 95\%. There is a significant influence between work motivation on the performance of the Pratama Pekanbaru Tampan Tax Office employee, because according to the results of the analysis $t$ count $>t$-table (2.007> 1.67) at $n=96$ with a significance level of $95 \%$. There is a significant effect between work stress on the performance of the Pratama Pekanbaru Tampan Tax Office employees, because according to the results of the t-count analysis $>t$-table ($1.605>1.67)$ at $n=96$ with a significance level of $95 \%$. Value of $F$-count $>F$ table $(14,321>2,46)$ together (multiple) there is a positive and significant influence of work environment, professional commitment, motivation and work stress on the performance of the Pratama Pekanbaru Tampan Tax Office employees. Thus the hypothesis proposed is accepted by the truth.
\end{abstract}

Keyword: Work environment, professional commitment, work motivation and stress and employee performance.

ABSTRAK : Masalah dalam peneltian ini adalah:bagaimana pengaruhlingkungan kerja, komitmen profesi, motivasi dan stress kerja secara parsial dan secara bersama-sama terhadapkinerja pegawaipadaKantor Pelayanan Pajak Pratama Pekanbaru Tampan ?. Tujuan penelitian :Untuk mengetahui pengaruh lingkungan kerja, komitmen profesi, motivasi dan stress kerjasecara parsial dan secara bersama-sama terhadapkinerja pegawai pada Kantor Pelayanan Pajak Pratama Pekanbaru Tampan. Hipotesis yang diajukan adalah :Lingkungan kerja, komitmen profesi, motivasi dan stress kerja berpengaruh signifikan secara parsial dan bersamaan terhadap kinerja pegawai pada Kantor Pelayanan Pajak Pratama Pekanbaru Tampan. Penelitian dilakukandi Kantor Pelayanan Pajak Pratama Pekanbaru Tampan Jalan Ring Road Arengka II/Jalan SM Amin Simpang Baru Pekanbaru, dengan populasi sebanyak98orang, dan sampel penelitian sebanyak 96 orang. Berdasarkan hasil analisis diperoleh Ada pengaruh yang signifikan antara lingkungan kerja terhadapkinerja pegawai Kantor Pelayanan Pajak Pratama Pekanbaru Tampan, karena menurut hasil analisis thitung > t-tabel $(2,932>1,67)$ pada $n=96$ dengan taraf sifgifikansi $95 \%$.Ada pengaruh yang signifikan antara komitmen profesi erhadap kinerja pegawai Kantor Pelayanan Pajak Pratama Pekanbaru Tampan,nhasil analisis thitung > t-tabel (1,975> 1,67) pada $n=96$ dengan taraf sifgnifikansi 95\%.Ada pengaruh yang signifikan antara motivasi 
kerja terhadap kinerja pegawai Kantor Pelayanan Pajak Pratama Pekanbaru Tampan, karena menurut hasil analisis thitung > t-tabel $(2,007>1,67)$ pada $n=96$ dengan taraf sifgnifikan $95 \%$. Ada pengaruh yang signifikan antara stress kerja terhadap kinerja pegawai Kantor Pelayanan Pajak Pratama Pekanbaru Tampan, karena menurut hasil analisis thitung >t-tabel $(-1,605>1,67)$ pada $n=96$ dengan taraf sifgifikan 95\%.Nilai $F$-hitung $>F$ tabel $(14,321>2,46)$ secara bersamasama (multiple) terdapat pengaruh positif dan signifikan lingkungan kerja, komitmen profesi, motivasi danstress kerja terhadap kinerja pegawai Kantor Pelayanan Pajak Pratama Pekanbaru Tampan. Dengan demikian hipotesis yang diajukan diterima kebenarannya.

Keyword : Lingkungan kerja, komitmen profesi, motivasi dan stress kerja serta kinerja pegawai.

\section{Pendahuluan}

Setiap Organisasi menuntut adanya pengelolaan organisasi, salah satu dimensi kegiatan organisasi yang memerlukan pendekatan baru di dalam pengelolaannya adalah pendayagunaan sumber daya manusia untuk mencapai tujuan organisasi yang diharapkan yakni kinerja organisasi. Kinerja organisasi tidak lepas dari kinerja pegawai sebagai salah satu unsur organisasi yang memegang peranan penting dalam usaha mencapai tujuan organisasi. Oleh sebab itu dalam organisasi apapun tanpa manusia maka tujuan organisasi yang telah ditentukan tidak akan tercapai sebagaimana yang diharapkan. Organisasi yang didirikan pada dasarnya ingin mencapai tujuan dan sasaran yang telah disepakati bersama dengan tindakan yang dilakukan bersama-sama dengan penuh rasa tanggung jawab. Selanjutnya organisasi yang berhasil dapat diukur dengan melihat sejauh mana organisasi tersebut dapat mencapai tujuan yang sudah ditetapkan.Untuk melihat organisasi dapat mencapai tujuan tidak lepas dari kinerja yang dihasilkan para pegawai.

Kinerja pegawai dalam organisasi adalah hasil secara kualitas dan kuantitas yang dicapai seseorang pegawai dalam melakasanakan tugasnya sesuai dengan tanggung jawab yang diberikan kepadanya. Kinerja seseorang pegawai pada dasarnya adalah hasil kerja seorang pegawai selama periode tertentu dibandingkan dengan berbagai kemungkinan, misalnya standar, target atau sasaran, atau kriteria yang telah ditentukan terlebih dahulu dan telah disepakati bersama, dengan memperhatikan berbagai situasi dan kondisis yang mempengaruhi prestasi kerja. Melihat kinerja pegawai setiap saat tertentu akan dilihat dan dinilai bagaimana perkembangannya untuk periode berikutnya atau masa berikutnya. Untuk itu pencapai tujuan organisasi yang diperoleh tidak saja tercapainya kinerja akan tetapi kinerja pegawai ada peningkatan dari masa sebelumnya. Oleh sebab itu pimpinan harus memperhatikan lingkungan kerja pegawai karena lingkungan kerja merupakan kondisi yang bersangkutan pada saat tempat kerja dibentuk perusahaan. Sejalan dengan pendirian perusahaan, manajemen perusahaan selayaknya mempertimbangkan lingkungan kerja bagi pegawai perusahaan. Perencanaan lingkungan kerja berarti menentukan susunan semua komponen fisik maupun non fisik yang mendukung aktivitas kerja karyawan.Kinerj di Kantor Pelayanan Pajak Pratama Pekanbaru Tampan belum maksimal, ini disebabkan karena lingkungan kerja yang kurang menduku, kurangnya komitmen profesi, motivasi pegawai dan adanya pegawai yang stress.

Komitmen profesional pegawai terhadap organisasi sangat diperlukan untuk menciptakan iklim kerja yang baik dalam organisasi. Komitmen dapat diartikan sebagai sikap pegawai untuk tetap berada dalam organisasi dan terlibat dalam upaya-upaya mencapai misi, nilai-nilai dan tujuan organisasi. Komitmen terhadap organisasi ini dipandang penting karena pegawai yang memiliki komitmen yang tinggi terhadap organisasi akan memiliki sikap yang profesional dan menjunjung tinggi nilainilai yang telah disepakati dalam organisasi. Untuk membangun komitmen pofesional individu terhadap organisasi dapat dilakukan melalui pendekatan lunak dan pendekatan keras. Pendekatan lunak dilakukan dengan menumbuhkan motivasi kerja pegawai. Hal ini dilakukan dengan cara melibatkan mereka dalam proses pengambilan keputusan dan membangun kultur organisasi yang berbasis teamwork dan kepercayaan. Ekspansi keterlibatan pegawai dalam pengambilan keputusan adalah inti dari rencana komitmen. Selanjutnya pendekatan keras yang dilakukan berkaitan dengan 3 faktor yang saling berkaitan yakni : sistem rekruitmen dan seleksi, sistem pelatihan, sistem pengembangan. 
Sejalan dengan adanya kemauan pegawai untuk bekerja atau mencurahkan tenaga dan pikirannya maka tidak lepas dari peran pimpinan organisasi dalam upaya memberdayakan SDM. Karena memberdayakan SDM tidak lepas dari peran kepemimpinan. Oleh sebab itu perlu dukungan dari pimpinan baik pimpinan personalia maupun pimpinan organisasi sehubungan dengan aplikasi manajemen yakni memotivasi pegawai agar pegawai memiliki kepuasan kerja dan memiliki kinerja yang tinggi

Terkadang ada pegawai tidak memiliki prestasi kerja karena adanya tekanan, beban kerja atau lainnya, ketegangan, panik, perasaan gemuruh, murung dan hilang semangat atau daya kerja. Kondisi seperti ini merupakan suatu kondisi ketidak seimbangan fisik dan fisikis, yang mempengaruhi emosi, proses berfikir, dan kondisi seorang pegawai yang mengakibatkan pegawai stress. Pegawai yang mengalami stress akan merugikan diri sendiri dan organisasi, karena pegawai yang mengalami stress akan tidak mampu menyelesaikan tugas-tugas yang dibebankan kepadanya dengan baik bahkan bila strees pegawai berkelanjutan akan sangat merugikan organisasi. Oleh sebab itu agar pegawai tidak mengalami stress yang tinggi atau kronis maka organisasi harus melakukan pendekatan bila muncul gejala stress pada pegawai seperti misalnya melakukan perbaikan iklim organisasi, menyediakan sarana olahraga, pimpinan melakukan analisis dan kejelasan tugas, meningkatkan keikutsertaan pegawai dalam pengambilan keputusan atau melakukan restrukturisasi tugas. Pendekatan ini merupakan pendekatan dari sisi organisasi dan ditambah dengan pendekatan individu meliputi meningkatkan keimanan, melakukan kegiatan olahraga dan menghindari kebiasaan rutin yang membosankan.

Berdasarkan uraian di atas kinerja pegawai dapat tercapai dengan baik apabila dilakukan perbaikan terhadap karakteristik Individu pegawai, penyeimbangan kerja dan jumlah pegawai dan lingkungan kerja pegawaiBertitik tolak dari kenyataan di atas menjadi latar belakang bagi penulis untuk mencoba mengangkat permasalahan tersebut kedalam tulisan yang berbentuk tesis. Sebagai objek penelitian penulis mengadakan penelitian dan pengamatan dengan judul : "Pengaruh Lingkungan Kerja, Komitmen Profesi dan Stres Kerja Terhadap Kinerja Pegawai Pada Kantor Pelayanan Pajak Pratama Pekanbaru Tampan.
Setiap kegiatan mempunyai tujuan tertentu, demikian juga dengan pelaksanaan penelitian ini bertujuan :

1. Untuk mengetahui pengaruh lingkungan kerja terhadap kinerja pegawai pada Kantor Pelayanan Pajak Pratama Pekanbaru Tampan

2. Untuk mengetahui pengaruh komitmen pofesiterhadap kinerja pegawai pada Kantor Pelayanan Pajak Pratama Pekanbaru Tampan

3. Untuk mengetahui pengaruh motivasi kerja terhadapkinerja pegawaipada Kantor Pelayanan Pajak Pratama Pekanbaru Tampan

4. Untuk mengetahui pengaruh stress kerja terhadapkinerja pegawaipada Kantor Pelayanan Pajak Pratama Pekanbaru Tampan

5. Untuk mengetahui pengaruh lingkungan kerja, komitmen profesi, motivasi dan stress kerjasecara bersama-samaterhadapkinerja pegawai pada Kantor Pelayanan Pajak Pratama Pekanbaru Tampan

\section{Metode Penelitian \\ 2.1. Lokasi Penelitian}

Lokasi penelitian dilakukan di Kantor Pelayanan Pajak Pratama Pekanbaru Tampan Jalan Ring Road Arengka II/Jalan SM Amin Simpang Baru Pekanbaru

\subsection{Populasi dan Sampel}

Populasi adalah totalitas dari semua objek atau individu yang memiliki karakteristik tertentu jelas dan lengkap yang akan diteliti. Adapun yang menjadi populasi dalam penelitian ini adalah seluruh Pegawai Kantor Pelayanan Pajak Pratama Pekanbaru Tampan yang berjumlah 98 0rang. Mengingat jumlah pegawai hanya 98 orang maka sampel penulis tetapkan seluruh populasi kecuali kepala kantor dan wakil kepala. Dengan demikian jumlah sampel 96 orang, dengan perincian sebagai berikut.

Tabel 1

Populasi Penelitian

\begin{tabular}{|c|l|c|}
\hline No & Jabatan & Jumlah \\
\hline 1. & Kepala Seksi & 10 orang \\
\hline 2 & Account Representative & 32 orang \\
\hline 3. & Pelaksana & 29orang \\
\hline 4. & Fungsional & 25 orang \\
\hline \multicolumn{2}{|c|}{ Jumlah } & 96 orang \\
\hline
\end{tabular}




\subsection{Teknik Analisa Data}

Teknik analisis data menggunakan validitas dan realibilitas, uji asumsi klasik dengan menggunakan uji Multikolinearitas, Multikolinearitas,

Heteroskedastisitas.Pengujian

Uji

menggunakan uji regresi berganda.

\section{Analisa dan Pembahasan}

\subsection{Analisis Regresi}

Setelah dilakukan uji asumsi klasik maka dapat dilakukn untuk penggunaan analisis
regresi.Analisis regresi digunakan untuk menganalisis data hasil penelitian dengan maksud untuk memperoleh gambaran hubungan fungsional antara variabel bebas dengan variabel terikat Hubungan fungsional antara variabel bebas dengan variabel terikat digunakan analisis regresi linier berganda

Berdasarkan analisis regresi linier ganda (Multiple) sebagaimana pada tabel dibawah ini diperoleh koefisien regresi sebagai berikut.

Tabel 2

Koefisien Regresi

\begin{tabular}{|c|c|c|c|c|c|}
\hline \multirow[b]{2}{*}{ Model } & \multicolumn{2}{|c|}{$\begin{array}{l}\text { Unstandardized } \\
\text { Coefficients }\end{array}$} & \multirow{2}{*}{$\begin{array}{c}\text { Standardized } \\
\text { Coefficients }\end{array}$} & \multirow[b]{2}{*}{$\mathrm{t}$} & \multirow[b]{2}{*}{ Sig. } \\
\hline & $\mathrm{B}$ & Std. Error & & & \\
\hline $1 \quad$ (Constant) & 28,559 & 3,275 & & 8,720 &, 000 \\
\hline Lingkungan kerja &, 147 &, 050 & ,303 & 2,932 & ,004 \\
\hline Komitmen profesi & , 128 & ,065 & ,207 & 1,975 & 051 \\
\hline Motivasi & ,099 & 049 & ,202 & 2,007 & 048 \\
\hline Stress kerja &,- 137 & ,085 &,- 135 & $-1,605$ &, 112 \\
\hline
\end{tabular}

Sumber : Hasil SPSS, 2019

Berdasarkan table 5.18diperoleh koefisien regresi variabel Lingkungan kerja kerja 0,147 komitmen profesi $=0,128$, Motivasi 0,099 stress kerja -0,137 dengan konstanta 22,559, maka dapat dituliskan persamaan regresi sebagai berikut.

$$
\begin{aligned}
& Y=22,559+0,147 X_{1}+0,128 X_{2}+0,167 X_{3}- \\
& \mathbf{0 , 1 3 7}
\end{aligned}
$$

Persamaan di atas menunjukkan konstanta bernilai positip dan nilai koefisien regresi lingkungan kerja, komitmen profesi dan motivasi sedangkan stress kerja koefisien regresi negatip.Hal ini memberi gambaran bahwa perubahan rata-rata variabel Kinerja Pegawai (Y) tergantung dari perubahan variabel Lingkungan kerja kerja $\left(\mathrm{X}_{1}\right)$, fasilitas kerja $\left(\mathrm{X}_{2}\right)$ motivasi dan stress kerja. Artinya apabila Lingkungan kerja, fasilitas kerja, Motivasi ditingkatkan (semakin baik) akan diikuti perubahan/kinerja pegawai. Selanjutnya apabila stress kerja dikurangi maka akan meningkatkan kinerja. Perubahan ini merupakan peningkatan apabila bertanda positip dan penurunan atau pengurangan jika bertanda negatif.Hal ini menunjukkan bahwa ada pengaruh Lingkungan kerja, fasilitas kerja, Motivasi terhadap kinerja pegawai.

\subsection{Uji Hipotesis \\ 3.2.1. Uji t- (Parsial)}

Untuk mengetahui pengaruh variabel bebas terhadap variabel terikat secara parsial digunakan uji t, dimana dengan ketentuan :

t- hitung $\leq \mathrm{t}$ - tabel ...............tidak ada pengaruh variabel bebas terhadap variabel terikat secara parsial

t- hitung > t- tabel ................Ada pengaruh variabl bebas terhadap variabel terikat secara parsial

derajat kebebasan $(\mathrm{dk})=\mathrm{n}-2$ dan Tingkat kepercayaan $\alpha=0,05$, 
Tabel 3

$\mathrm{Uji}$ - $\mathrm{t}$ (Parsial)

\begin{tabular}{|c|c|c|c|c|c|c|}
\hline \multicolumn{7}{|c|}{ Coefficients $^{\mathrm{a}}$} \\
\hline \multirow{2}{*}{\multicolumn{2}{|c|}{ Model }} & \multicolumn{2}{|c|}{ Unstandardized Coefficients } & \multirow{2}{*}{$\begin{array}{c}\text { Standardized } \\
\text { Coefficients }\end{array}$} & \multirow[b]{2}{*}{$\mathrm{t}$} & \multirow[b]{2}{*}{ Sig. } \\
\hline & & B & Std. Error & & & \\
\hline \multirow[t]{5}{*}{1} & (Constant) & 28.559 & 3.275 & & 8.720 & .000 \\
\hline & Lingkungan kerja & .147 & .050 & .303 & 2.932 & .004 \\
\hline & Komitmen profesi & .128 & .065 & 207 & 1.975 & .051 \\
\hline & Motivasi & .099 & .049 & .202 & 2.007 & .048 \\
\hline & Stress ker & -.137 & .085 & -.135 & -1.605 & .112 \\
\hline
\end{tabular}

a. Dependent Variable: Kinerja pegawai

Berdasarkan hasil analisis pada tabel 3 diatas; diperoleh nilai t-Lingkungan kerja $=$ 2,932, sedangkan t-tabel dengan $\mathrm{dk} 96$ (Lampiran) sebesar 1,67 maka thitung > t-tabel dengan demikian secara parsial ada pengaruh yang signifikan antara Lingkungan kerja kerja terhadap kinerja pegawai.

Selanjutnya nilai $\mathrm{t}$ komitmen profesi $=$ 1,975, sedangkan t-tabel dengan $\mathrm{dk} 96$ (Lampiran) sebesar 1,67 maka t hitung $>\mathrm{t}$ tabel dengan demikian secara parsial ada pengaruh yang signifikan antara komitmrn profesiterhadap Kinerja Pegawai..

Nilai t Motivasi $=2,007$, sedangkan t-tabel dengan dk 96 (Lampiran) sebesar 1,67 maka t hitung $>\mathrm{t}$ tabel dengan demikian secara parsial ada pengaruh yang signifikan antara Motivasi terhadap Kinerja Pegawai.

Nilai t stress kerja $=-1,605$, sedangkan $\mathrm{t}$ tabel dengan dk 96 (Lampiran) sebesar 1,67 maka $\mathrm{t}$ hitung $<\mathrm{t}$ tabel dengan demikian secara parsial tidak ada pengaruh yang signifikan antara stress kerjaterhadap Kinerja Pegawai.

\subsubsection{Uji F (Simultanl)}

Untuk mengetahui pengaruh variabel bebas secara bersama-sama terhadap variabel terikat digunakan uji-F, (Sudjana, 2013:355) dengan rumus:

$$
: F_{\text {hit }}=\frac{J K_{\text {reg }} / k}{J K_{r e s} /(n-k-1)}
$$

Dimana :

$\mathrm{JK}_{\text {reg }}=$ Jumlah kuadrat regresi

$\mathrm{JK}_{\mathrm{reg}}=$ Jumlah kuadrat residu

$\mathrm{n}=$ Jumlah Sampel

$\mathrm{K}=$ Jumlah varians

Jika : $\mathrm{F}$ hitung > F tabel : Hipotesis Alternatip (Ha) diterima

$\mathrm{F}$ hitung $<\mathrm{F}$ tabel : Hipotesis (Ho)

ditolak

Penelitian ini menggunakan tingkat kepercayaan $95 \%(\alpha=0.05)$

Tabel 3

Uji - F (Simultan)

ANOVA $^{\mathrm{a}}$

\begin{tabular}{|rl|r|r|r|r|r|}
\hline \multicolumn{1}{|l|}{ Model } & Sum of Squares & df & Mean Square & F & Sig. \\
\hline 1 & Regression & 56.302 & 4 & 14.076 & 14.321 & $.000^{\mathrm{b}}$ \\
& Residual & 89.438 & 91 & .983 & & \\
& Total & 145.740 & 95 & & & \\
\hline
\end{tabular}

a. Dependent Variable: Kinerja pegawai

b. Predictors: (Constant), Stress ker, Lingkungan kerja, Motivasi, Komitmen profesi 
Berdasarkan analisis varians (Anova) pada lampiran 10 diketahui nilai F-hitung sebesar 14,321 sedangkan nilai F-tabel (Lampiran) dengan $\mathrm{dk}$ pembilang $4 \mathrm{dan} \mathrm{dk}$ penyebut 91 adalah sebesar 2,46 dimana F-hitung > F tabel $(14,321>2,46)$ maka dapat disebutkan bahwa secara bersama-sama (multiple) terdapat pengaruh positif dan signifikan Lingkungan kerja, komitmen profesi, Motivasi dan stress kerja terhadap kinerja pegawai. Dengan demikian hipotesis yang diajukan diterima kebenarannya.

\subsubsection{Uji Determinasi}

Berdasarkan hasil analisis data Lingkungan kerja kerja di Kantor Pelayanan Pajak Pratama Pekanbaru Tampan kategori kurang tinggi, komitmen profesi kurang baik, Motivasi kurang tinggi, stress kerja kurang rendah dan Kinerja
Pegawai juga kurang tinggi.Hasil analisis data sesuai hasil ANOVA Kinerja Pegawai dapat meningkat apabilaLingkungan kerja kerja semakin baik, komkitmen kerja juga semakin baik, Motivasi semakin tinggi dan stress kerja semakin rendah. Oleh sebab itu juga pengujian hipotesis diperoleh terdapat pengaruh signifikan Lingkungan kerja, komitmen profesi, Motivasi dan stress kerjaterhadap kinerja pegawai. Apabila Lingkungan kerja, komitmen profesi, Motivasi ditingkatkan $1 \%$ maka Kinerja Pegawai akan naik 1\% dan apabila stress kerja dikurangi 1\% maka kinerja naikm sebesar 15 . Besarnya pengaruh Lingkungan kerja komitmen profesi, Motivasi dan stress kerja terhadap Kinerja Pegawai dapat diketahui melalui uji determinasi (D) dimana $D=R^{2} \times 100 \%$. Hasil analisis pada model summary sebagaimana pada tabel 4 sebagai berikut.

Tabel 4

Model Summary

\begin{tabular}{|l|l|l|l|l|l|}
\hline Model & $\mathrm{R}$ & $\mathrm{R}$ Square & $\begin{array}{l}\text { Adjusted R } \\
\text { Square }\end{array}$ & $\begin{array}{l}\text { Std. Error of } \\
\text { the Estimate }\end{array}$ & $\begin{array}{l}\text { Durbin- } \\
\text { Watson }\end{array}$ \\
\hline 1 & $.622^{\mathrm{a}}$ & .386 & .359 & .99138 & 1.552 \\
\hline
\end{tabular}
a. Predictors: (Constant), Stress ker, Lingkungan kerja, Motivasi, Komitmen profesi
b. Dependent Variable: Kinerja pegawai

Berdasarkan tabel 4 diketahui $\mathrm{R}^{2}=0,386$ maka $\mathrm{D}=0,386 \mathrm{x} 100 \%$ sehingga $\mathrm{D}=38,6 \%$. Dengan demikian pengaruh lingkungan kerja, komitmen profesi, Motivasi dan stress kerjaterhadap Kinerja Pegawai secara bersamasama sebesar 38,6\% yang berarti $61,4 \%$ lagi yang mempengaruhi kinerja pegawai ditentukan faktor lain yang tidak diteliti dalam penelitian ini seperti faktor loyalitas etos kerja dan lain sebagainya.

\section{A. Kesimpulan}

Sesuai hasil analisis penelitian maka dapat diambil kesimpulan sesuai tujuan penelitian yang dikemukakan, sebagai berikut :

1. Ada pengaruh yang signifikan antara lingkungan kerja terhadap kinerja pegawai Kantor Pelayanan Pajak Pratama Pelanbaru Tampan, karenamenuruthasilanalisisthitung $>$ t-tabel $(2,932>1,67)$ pada $\mathrm{n}=96$ dengan taraf signifikansi $95 \%$.

2. Ada pengaruh yang signifikan antara komitmen profesi erhadap kinerja pegawai Kantor Pelayanan Pajak Pratama Pelanbaru Tampan,nhasilanalisisthitung > t-tabel $(1,975>1,67)$ pada $n=96$ dengan taraf signifikansi $95 \%$.
3. Ada pengaruh yang signifikan antara motivasi kerja terhadap kinerja pegawai Kantor Pelayanan Pajak Pratama Pelanbaru Tampan, karenamenuruthasilanalisisthitung $>$ t-tabel $(2,007>1,67)$ pada $\mathrm{n}=96$ dengan taraf signifikansi $95 \%$

4. Ada pengaruh yang signifikan antara stress kerja terhadap kinerja pegawai Kantor Pelayanan Pajak Pratama Pelanbaru Tampan, karenamenuruthasilanalisisthitung $>$ t-tabel $(-1,605>1,67)$ pada $n=96$ dengan taraf signifikansi $95 \%$.

5. Nilai F-hitung $>\mathrm{F}$ tabel $(14,321>2,46)$ secara bersama-sama (multiple) terdapat pengaruh positif dan signifikan lingkungan kerja, komitmen profesi,motivasi danstress kerja terhadap kinerja pegawai Kantor Pelayanan Pajak Pratama Pelanbaru Tampan. Dengan demikian hipotesis yang diajukan diterima kebenarannya.

\section{DAFTAR PUSTAKA}

Abdulrachman, Arifin, 2010, KerangkaPokokPokok Management, Gramedia, Jakarta.

AlwiSyafaruddin, 2011, ManajemenSumberDayaManusia, BPFE, UGM Yogyakarta 
As'ad, 2011, Penentuan Sepuluh Menit Penilaian Kinerja, Yogyakarta : Andi

Arikunto, Suharsimi, 2012. Prosedur Penelitian Suatu Pendekatan Praktek, Rineka Cipta, Jakarta

Bartos, Basir, 2011 ManajemenSumberDayaManusiaSuatuPen dekatanMakro, BumiAksara, Jakarta.

Dwiyanto, Agus,

2011

PenilaianKinerjaOrganisasiPelayananPubli k, UGM, Yogyakarta

Kreitner Robert, 2012, Organizational Behavior, (PerilakuOrganisasi),TerjemahanErlySuan dy, PenerbitSalembaEmpat, Jakarta

Mangkuprawira, Sjafri, 2012, ManajemenSumberDayaStrategik, PenerbitGhalia Indonesia, Jakarta.

Manullang, M.2010 ManajemenSumberDayaManusia, Ghalia Indonesia, Jakarta.

Mitrani, Alain,

2010 ManajemenSumberDayaManusiaBerdasar kanKompetensi, PustakaUtamaGrafiti, Jakarta

Moenir

AS,

2010 PendekatanManusiawidanOrganisasiTerha dapPembinaanPegawai,GunungAgung, Jakarta

Nitisemito,Alex,S, 2011 , ManajemenPersonalia, Ghalia Indonesia, Jakarta

Ranupandojo.Heidjrahman dan Suad Husnan, 2009, Manajemen Personalia, : BPFE, Yogyakarta.

RivaiVeithzal, 2013 , ManajemenSumberDayaManusiauntuk Perusahaan dariteorikePraktek, PT. RajagrafindoPersada, Jakarta.

Rohani Ahmad, 2009. PengelolaanPengajaran, RinekaCipta, Jakarta

Siagian, S.P,2010 : Organisasi, KepemimpinandanPrilakuOrganisasi, GunungAgung, Jakarta.

Sinungan, Muchdarsyah, 2011, ProduktivitasApadanBagaimana, BumiAksara, Jakarta

Sedarmayanti, 2012 SumberDayaManusiadanProduktivitasKerj a,PenerbitIlham Jaya, Bandung

Sudjana, 2011, Metoda Statistika, Tarsito, Bandung.

Sugiyono, 2013, Metode Penelitian Kuantitatif, Kualitatif dn R\&D, Cetakan 10, Penerbit Alfabeta Bandung.
Susilo, Willy, 2009, MotivasiIntrinsik, Jakarta, VorqistatamaBinamega,

Tangkilisan, Hessel Nogi, S, 2011, Manajemen Publik,: PT. Grasindo, Jakarta

Thoha, Miftah, 2011, PerilakuOrganisasi, Raja GrafindoPersada, Jakarta.

Tohardi

.2012 , SumberDayaManusiadanLingkunganKerja , Cet. 3, Jakarta: Rajawali Press

Wijaya Tony, 2011, CeparMenguasai SPSS UntukOlah\&Interpretasi Data Penelitian, CahayaAtma Yogyakarta. 